Türk Turizm Araştırmaları Dergisi
2021, 5(1): $19-33$.

\title{
Turizm Öğrencilerinin Endüstri 4.0 Kavramsal Farkındalık Düzeyleri ve Teknoloji Kullanım Alışkanlıkları Arasındaki İlişki*
}

Dr. Öğr. Üyesi Ersin ARIKAN, Sinop Üniversitesi, Turizm İşletmeciliği ve Otelcilik Yüksekokulu, Sinop, eposta: earikan@sinop.edu.tr

ORCID: https://orcid.org/0000-0002-6171-1813

Doç. Dr. Ali Turan BAYRAM, Sinop Üniversitesi, Turizm İşletmeciliği ve Otelcilik Yüksekokulu, Sinop, eposta: alibayram@sinop.edu.tr ORCID: https://orcid.org/0000-0003-1655-4043

Arş. Gör. Hasan Tahsin KAVLAK, Sinop Üniversitesi, Turizm İşletmeciliği ve Otelcilik Yüksekokulu, Sinop, e-posta: htkavlak@sinop.edu.tr

ORCID: https://orcid.org/0000-0003-0036-9652

Doç. Dr. Gül ERKOL BAYRAM, Sinop Üniversitesi, Turizm İşletmeciliği ve Otelcilik Yüksekokulu, Sinop, e-posta: gulerkol@sinop.edu.tr

ORCID: https://orcid.org/0000-0001-9764-2883

\section{Öz}

Endüstri 4.0 kavramı son yıllarda üretim ve pazarlama anlayışı temelinde hız, verimlilik, maliyet ve inovasyon odaklı süratle gelişen teknolojilerle yeni bir yaklaşım olarak değerlendirilmektedir (Soylu, 2018). Bu kapsamda değerlendirildiğinde Endüstri 4.0 ile ilgili bilgi ve farkındalık düzeyinin tespit edilmesi ve geliştirilmesi gelişen teknolojinin izlenmesi açısından önemlidir. Bağlamda söz konusu bu çalışmanın amacı, turizm öğrencilerinin Endüstri 4.0 kavramsal farkındalık düzeyleri ile teknoloji kullanım alışkanlıkları arasındaki ilişkiyi ortaya çıkarmaktır. Bu çalışmada veriler 2019-2020 eğitim öğretim yılında Sinop Üniversitesi Turizm İşletmeciliği ve Otelcilik Yüksekokulu'nda anket tekniği kullanılarak toplanmıştır. Verilerin analizinde bağımsız iki örnek t-testi, varyans analizi ve korelasyon analizi kullanılmıştır. Araştırma neticesinde, araştırmaya katılan öğrencilerin Endüstri 4.0 kavramsal farkındalık düzeylerinin ve teknoloji kullanım alışkanlıklarının çeşitli değişkenler açısından farklılık gösterdiği tespit edilmiştir. Buna ek olarak araştırmaya katılan öğrencilerin Endüstri 4.0 kavramsal farkındalık düzeyleri ile teknoloji kullanım alışkanlıkları arasında da pozitif yönlü bir ilişki saptanmıştır.

* Bu çalışma MTCON'20 Kitalararası Turizm Yönetimi Konferansı'nda bildiri olarak sunulan “Turizm Öğrencilerinin Endüstri 4.0 Kavramsal Farkındalık Düzeylerini ve Teknoloji Kullanım Alışkanlıklarını Belirlemeye Yönelik Bir Araştırma" adlı çalışmanın genişletilmiş halidir.

Anahtar Kelimeler: Endüstri 4.0, Teknoloji Bağımlılığı, Teknoloji Farkındalığı.

Makale Gönderme Tarihi: 05.10.2020

Makale Kabul Tarihi: 01.03.2021

Önerilen Atıf:

Arıkan, E., Bayram, A. T., Kavlak, H. T. ve Erkol Bayram, G. (2021). Turizm Öğrencilerinin Endüstri 4.0 Kavramsal Farkındalık Düzeyleri ve Teknoloji Kullanım Alışkanlıkları Arasındaki İlişki, Türk Turizm Araştırmaları Dergisi, 5(1): 19-33.

(C) 2021 Türk Turizm Araştırmaları Dergisi. 


\title{
Journal of Turkish Tourism Research \\ 2021, 5(1): 19-33. \\ DOI: $10.26677 /$ TR1010.2021.649 \\ ISSN: 2587-0890 Journal Homepage: https://www.tutad.org \\ RESEARCH PAPER
}

\section{The Relationship Between Tourism Students 'Industry 4.0 Conceptual Awareness Levels and Technology Use Habits}

Assistant Prof. Dr. Ersin ARIKAN, Sinop University, School of Tourism and Hotel Management, Sinop, email: earikan@sinop.edu.tr

ORCID: https://orcid.org/0000-0002-6171-1813

Associate Prof. Dr. Ali Turan BAYRAM, Sinop University, School of Tourism and Hotel Management, Sinop, e-mail: alibayram@sinop.edu.tr

ORCID: https://orcid.org/0000-0003-1655-4043

Research Assistant Hasan Tahsin KAVLAK, Sinop University, School of Tourism and Hotel Management, Sinop, e-mail: htkavlak@sinop.edu.tr

ORCID: https://orcid.org/0000-0003-0036-9652

Associate Prof. Dr. Gül ERKOL BAYRAM, Sinop University, School of Tourism and Hotel Management, Sinop, e-mail: gulerkol@sinop.edu.tr

ORCID: https://orcid.org/0000-0001-9764-2883

\begin{abstract}
The concept of Industry 4.0 has been considered as a new approach with rapidly developing technologies focused on speed, efficiency, cost and innovation on the basis of production and marketing understanding (Soylu, 2018). When evaluated in this context, it is important to determine and develop the level of knowledge and awareness about Industry 4.0 in terms of monitoring the developing technology. In this context, the aim of this study is to reveal the relationship between tourism students' Industry 4.0 conceptual awareness levels and their technology usage habits. In this study, the data were collected in the 2019-2020 academic year at Sinop University School of Tourism Management and Hotel Management using the survey technique. Two independent samples t-test, variance analysis and correlation analysis were used to analyse the data. As a result of the research, it was determined that the Industry 4.0 conceptual awareness levels and technology usage habits of the students participating in the research differ in terms of various variables. In addition, a positive relationship was found between the Industry 4.0 conceptual awareness levels of the students participating in the study and their technology usage habits. Based on these results, suggestions have been developed to contribute to universities and the literature.
\end{abstract}

Keywords: Industry 4.0, Technology Addiction, Technology Awareness.

Received: 05.10.2020

Accepted: 01.03.2021

Suggested Citation:

Arıkan, E., Bayram, A. T., Kavlak, H. T. and Erkol Bayram, G. (2021). The Relationship Between Tourism Students 'Industry 4.0 Conceptual Awareness Levels and Technology Use Habits, Journal of Turkish Tourism Research, 5(1): 19-33.

(C) 2021 Türk Turizm Araştırmaları Dergisi. 


\section{Gíriş}

İlk Sanayi Devrimi'nden bu yana, sonraki devrimler, su ve buharla çalışan makinelerden elektrikli ve dijital otomatik üretime kadar üretimde köklü değişikliklere neden olmuştur. Üretim süreçleri giderek daha karmaşık, otomatik ve sürdürülebilir bir yapıya dönüşmesi, insanların makineleri basit, verimli ve kalıcı bir şekilde çalıştırabileceği bir yapıyı beraberinde getirdiği söylenebilir (Wahlster, 2012). Endüstriyel üretim, günümüzde küresel rekabet ve üretimin sürekli değişen pazar taleplerine hızlı bir şekilde uyarlanması ihtiyacından kaynaklandığı söylenebilir. Bu gereksinimler yalnızca mevcut üretim teknolojisindeki köklü gelişmelerle karşılanabileceği düşünülebilir. Endüstri 4.0, iş ve üretim süreçlerinin bir bütün olarak değerlendirilebileceği ve işletmelerin değer zincirindeki tüm aktörlerin de (tedarikçiler ve müşteriler) bir bütün olarak gören yaklaşım olarak incelenmektedir (Rojko, 2017). Dijital, fiziksel ve beşerî dünyanın entegrasyonunun bir zorunluluk haline gelmesi her sektörde derin bir dönüşüm yaratmakta ve Endüstri 4.0 olarak tanımlanan dördüncü sanayi devriminin başlaması ve gelişmesine olanak sağladığı düşünülmektedir (Zio, 2016). Bu kapsam da değerlendirmeler yapmanın bir gereklilik haline gelmesiyle Endüstri 4.0 işletmeler için büyük fırsatları da beraberinde getirebilmektedir. Günümüzde, Endüstri 4.0'in getirdiği fırsatlar ve zorluklarla başa çıkmak için stratejilerin yeni duruma göre nasıl ayarlanacağı üzerinde sıklıkla durulan bir konu haline gelmektedir (Zhou ve Le Cardinal, 2019). Bu amaç doğrultusunda işletmelerin farkındalıklarının artmasıyla birlikte sektörler ve işletmeler kendi anlayışlarına ve alanlarına göre Endüstri 4.0'ü farklı tanımlamalarla (Nesnelerin İnterneti, Siber fiziksel sistemler, Akıllı Sistemler, Dijitalleşme ve Dijital Fabrika vb. gibi) ortaya koymaktadırlar. (Khan ve Turowski, 2016). Bu bağlamda değerlendirildiğinde sektörlerin, işletmelerin ve bu alanlarda çalışan iş gören ve yöneticilerin yenilikleri ve değişimi yakından takip etmeleri için öncelikle kavramlara yönelik farkındalıklarının sağlanmasının önemi ortaya çıkmaktadır. Söz konusu bu farkındalık noktasında Nuroğlu ve Nuroğlu (2018) sanayide dijital dönüşümün gerçekleştirilmesinin, bölgesel eğitimlere yükseköğretim kurumlarının katılımlarının sağlanmasının ve kavramsal olarak sağlanan farkındalığın arttırılmasına yönelik kampanyalar ile eğitim programlarının önemini vurgulamaktadırlar.

Çeşitli sektörlerde ve bilgi işlem dünyasında meydana gelen yenilikler doğrultusunda Endüstri 4.0 kavramı, küresel rekabet ortamında kârlılıklarını arttırmak ve devamlılıklarını sağlamak isteyen endüstriyel işletmelerin de önem verdiği bir konu haline gelmiştir. Bu ve bunun gibi nedenlerle Endüstri 4.0 sürecini iyi anlamak ve söz konusu bu devrim anlayışını oluşturan temel kriterleri benimsemek ve iş süreçlerine dahil etmek gerekmektedir (Gürsoy vd., 2019). Bu iş süreçleri içerisinde Endüstri 4.0' 1 n çerçevesini oluşturan yeni oluşumda program yazabilen, bu programları etkin bir biçimde kullanabilen, robotları ve makineleri üretebilen kişilere ihtiyaç duyulacağı düşünülmektedir. $\mathrm{Bu}$ bağlamda söz konusu değişikliği hızlı bir biçimde kavrayabilecek gelecekte yaşanabilecek hızlı değişimlere ayak uydurmaya yardımcı eğitim değişikliklerini planlamak gerekmektedir. Özellikle iş çevresinin gelecekte ihtiyaç duyacağ 1 gereksinimler için nelerin öğretileceği ve öğrenmeyi öğrenme kavramları üzerinde eğitim ihtiyacı ortaya çıkmaktadır (Özsoy, 2018).

\section{KAVRAMSAL ÇERÇEVE}

18. yüzyılın sonlarına doğru başlayan, 21. yüzyıla kadar süregelen ve 21. yüzyıl sonrası dönemde de hızı bir gelişim sağlaması düşünülen teknoloji, Endüstri 1.0 (1. Sanayi Devrimi), ile üretilen buharlı gemi ve lokomotifler, telgraflar, fabrikalarda mekanik makinelerin kullanılmasını, üretimin arttırılmasını, çalışma süresinin azaltılmasını, iletişimin ve ulaşımın kolaylaşmasını mümkün kılmıştır. Bunun akabinde Henry Ford'un öncülüğünde fabrikalarda kullanılan buharlı mekanik üretim yerini elektrikli seri üretime bırakmıştır. İkinci Dünya Savaşı́ndan sonra 
üretimde yenilik arayışları sürmüş, buharlı mekanik üretimin yerini alan elektrikli seri üretimin de yetersiz olduğu görülmüş ve üretimde dijital teknoloji kullanılmaya başlanmıştır. Bilgisayarlarla birlikte otomasyon sistemleri daha verimli üretim yapılmasını sağlamıştır. Endüstri 1.0 'üretimde makineleşme', Endüstri 2.0 'seri üretim' ve söz konusu dijital teknolojinin kullanıldığı Endüstri 3.0 ise kısaca 'üretimde nicelik ve otomasyon' olarak ifade edilebilir.

İlk kez 2011 Hannover Fuarı'nda ifade edilen Endüstri 4.0, Endüstri 1.0, 2.0 ve 3.0'dan çok daha farklı bir anlayışa sahiptir (Ertuğrul ve Deniz, 2018). Departmanlar arası iletişimde üretime ilişkin verilerin eş zamanlı paylaşılması ve bu paylaşımla birlikte maksimum faydanın sağlanması (Brettel, Friederichsen, Keller ve Rosenberg, 2014) temeline dayanan Endüstri 4.0; 'sürekli artarak bireyselleşen müşteri isteklerine odaklanan, fikir aşamasından başlayarak bir ürünün son kullanıcıya dağıtımını ve geri dönüşümünü de kapsayacak şekilde tüm zinciri içine alan bir döngü' olarak ifade edilmektedir (Şimşek, 2019).

Endüstri 1.0'dan başlayan ve günümüzde Endüstri 4.0 ile devam eden ve her geçen gün üzerine yapılan çalışmaların arttı̆̆ bir diğer konu ise teknoloji kullanım alışkanlığı diğer bir ifade ile teknoloji bağımlılığıdır. Teknolojinin gelişimi ile birlikte teknolojiyi kullanan kişi sayısı da artmakta, bilgiye ulaşım kolaylaşmakta, büyük verileri işleme, çözümleme ve yeni bilgiler üretmeyi mümkün kılmakta, dolayısıyla da ekonomik ve sosyal değişimin önemli bir unsuru haline gelmektedir (İçli, 2001). Teknoloji bağımlılı̆̆ı kavramı literatürde incelendiğinde, kavramın isimlendirilmesinde farklı görüşlerin yer aldığı da görülmektedir. Örnek verilecek olursa literatürde yer alan isimlerden bazılarını şu şekilde sıralanabilmektedir; "Internet Băğmlılığı Rahatsızlığı' (Internet Addiction Disorder), 'Patolojik Internet Kullanımı' (Pathological Internet Use), 'Problemli İnternet Kullanımı' (Problematic Internet Use), 'Aşırı İnternet Kullanımı' (Excessive Internet Use), 'Takıntılı Internet Kullanımı' (Compulsive Internet Use), 'Çeorim içi Bă̆gmlilığı' (Online Addiction), 'Yüksek Internet Düşkünlüğ̈̈̈' (High Internet Dependancy)" (Widyanto ve Griffiths, 2006; akt: Ertemel ve Aydın, 2018).

Genel olarak teknoloji bağımlılığı, teknolojinin kullanan bireyler açısından olumsuz birtakım sonuçlar oluşturmasına rağmen her geçen gün artan bir biçimde teknoloji ile ilgili davranışların saplantılı hale gelmesi olarak tanımlanabilmektedir (Başar, 2019). Günümüz toplumsal yapı içerisinde gençler, teknoloji kullanımında önemli bir yere sahiptirler. Teknolojiyi hayatlarının merkezine koyan gençler, teknolojisiz bir hayatı kabullenememekte ve tüm ihtiyaçlarını internet üzerinden karşılamak isteyen, teknolojinin tüm araçlarını vücutlarının bir parçası gibi gören bireyler olarak yaşamlarını idame ettirmeye çalışmaktadır (Aksoy, 2018). Endüstri 1.0, 2.0 ve 3.0' da olduğu gibi Endüstri 4.0' da da yalnızca üretim değil sosyal hayat, insan ihtiyaçları, mesleki ve ticari olanaklar, bireylerin boş zaman dilimi, çalışma süreleri, mal ve hizmetlerden beklentiler, mal ve hizmetlerden sağlanan doyum gibi daha birçok faktörün değişiklik göstereceği düşünülmektedir (Jan Bartodziej, 2017: 27-28). Endüstri 4.0'1n konuşulduğu günümüz dünyasında bulut teknolojilerinin kullanımı ve büyük verilerin önemi daha önemli bir duruma gelmektedir. Bu süreçten sonra daha da hızlanan bir yapı içerisinde teknolojinin nasıl ve ne yöne doğru dönüşebileceği tahmin edilememektedir. Ancak insan ve makinenin, üretim araçlarını onların verimliliğini iyileştirmek için birlikte çalışma yolları arayan Endüstri 5.0 diye adlandırılan yeni bir devrim de yaklaşmaktadır. Endüstri 5.0'dan sonra hızlı bir biçimde sayısal olarak da adlandırmaların zorlaşacağı hız kavramının bile kendinde açıklanmayacağı devrimler, dönüşümler dönemi olabileceği tahmin edilebilir (Topsakal vd., 2018).

Endüstri 4.0 kavramı ile bilişim alt yapısının önemi daha da artmış ve günlük hayatta kullanılan ve uygulanan yeni kavramlar ve uygulamalar ortaya çımıştır. Genellikle mühendislik alanlarında kendisine uygulama alanı bulan, anlamı bilinmeyen ve sadece ismi bilinen kavramlar, Endüstri 4.0 akımı ile günlük hayata girmiştir. Bu kavramların bilinmesi ve doğal olarak anlaşılması kullanım alanını genişletebilecektir (Özsoylu, 2017). 
Endüstri 4.0 devrimi ile birlikte öncelikle gelişmiş ülkeler çalışmalar yapmakta ve Endüstri 4.0 ile ilgili konuşulan kavramlara yönelik yatırımlar yapmaktadırlar. Bu kapsamda Almanya, Amerika, Çin ve Finlandiya gibi ülkelerin Endüstri 4.0 ile ilgili yatırımlar ve çalışmalar yaptığı görülmektedir (Yıldız, 2018). Bu yatırımlar, işletmelerin artan rekabet ortamında faaliyetlerini verimli bir biçimde devam ettirebilmeleri için Endüstri 4.0'da yer alan yeni bilişim ve üretim teknolojilerine hızlı uyum sağlamalarını gerektirmektedir. Rekabetçi güç sağlamak amacıyla kalite ve maliyeti olumlu etkileyecek yöntemleri kullanmaları ve bu yöntemlere önem vermeleri gerekmektedir. Endüstri 4.0 ile gelen ve üzerinde konuşulan teknolojik üretim sistemleri ile hem kaliteli ve hatasız üretimi bununla birlikte işgücü kullanılmasından kaynaklı maliyetlerin azaltılmasını vaat etmektedir (Akben ve Avşar, 2018). Endüstri 4.0 ile birlikte tartışılan yeni bir konu, bu çağın ihtiyaç duyduğu insan kaynaklarının yetkinlik ve becerileridir. Bu ihtiyaca yönelik bu alana yönelecek işgücüne katılan bireylerin beceri eksikliklerini ve bu becerilerin kazandırılmasına yönelik neler yapılabileceği kapsamında araştırmalar önemlidir (Toker, 2018).

Hızla dijitalleşen dünyada ekranların gündelik yaşantı içerisinde daha fazla zaman kapladığı görülmektedir. Değişik kaynaklarda sürekli veri üretilmektedir. Üretilen bilgilerin farklı platformlarda tüketicilerin dikkatini çekebilmek için kıyasıya bir rekabet yaşanmaktadır (Ertemel ve Aydın, 2018). Bu kapsamda Endüstri 4.0 diğer bir ifade ile 4. Sanayi devrimi küresel çapta ekonomik, sosyal ve siyasal alanda gelişmeleri de etkilemektedir. Bu konu sadece üretim sistemleri ile değerlendirilemeyecek kadar karmaşık ve çok boyutlu bir biçimde işlenmektedir (Soylu, 2018). Bu farklı uygulamalar ve teknolojilere yönelik farkındalığın oluşturulması son derece önemlidir. Değişiklikleri takip etmek ve işletmeler için bu değişiklikleri sistemlere entegre etmek, eğitim kurumları için bu değişiklikleri uygulamak önem kazanmaktadır.

Teknolojinin gelişmesi beraberinde teknoloji okuryazarlığı gibi teknolojik sistemleri kullanan, geliştiren büyük bir kitlenin oluşmasını sağlamıştır. Bununla birlikte teknoloji bağımlılığı gibi kavramlar ortaya çıkmıştır. Son yıllarda üzerinde çalışmalar yapılan teknoloji ile ilgili çalışmalarla birlikte Endüstri 4.0'a yönelik çalışmaların akademik alanda daha fazla yapılmasına ihtiyaç vardır. Bu bağlamda değerlendirildiğinde söz konusu bu araştırma teknolojiyi en fazla kullanan ve yakından takip eden üniversite öğrencilerinin Endüstri 4.0 farkındalık düzeyleri ile teknoloji kullanım alışkanlıklarını belirlemek çalışmanın çıkış noktasını oluşturmaktadır. Buna ek olarak esnek yapısı gereği etkilenme eşiği çok yüksek olduğu düşünülen turizm sektöründe Endüstri 4.0'ın uygulanması, turizm sektöründe çalışan bireylerin bu akıma yönelik tepkileri, beklentileri, endişeleri, turizm eğitimi alan öğrencilerin bu akıma yönelik farkındalıkları gibi konular (Topsakal vd., 2018) da büyük merak konusu olarak görülmektedir. Bu noktadan hareketle bu araştırma, turizm öğrencilerinin Endüstri 4.0 kavramsal farkındalık düzeyleri ile teknoloji kullanım alışkanlıkları arasındaki ilişkiyi ortaya koymak amacıyla yapılmıştır. Araştırma sonuçlarından hareketle geliştirilen önerilerin öğretim kurumlarının eğitim-öğretim faaliyetlerine, devlet yönetim organlarının eğitim-öğretim politikalarına ve ilgili literatüre katkı sağlayacağ 1 düşünülmektedir.

\section{YÖNTEM}

Üniversitesi öğrencilerinin Endüstri 4.0 farkındalık ve teknoloji bağımlılık düzeylerinin belirlenmesi ve bu değişkenler arasındaki ilişkinin ortaya koyulması amacıyla yürütülen bu çalışmada, amaç doğrultusunda aşağıda yer alan sorulara yanıt aranmaya çalışılmıştır:

1. Cinsiyet bağımsız değişkenine göre, üniversite öğrencilerinin Endüstri 4.0 kavramsal farkındalıkları ve teknoloji bağımlılık düzeyleri açısından anlamlı bir farklılık var mıdır? 
2. Ortaöğretim mezuniyet alanı değişkenine göre, üniversite öğrencilerinin Endüstri 4.0 kavramsal farkındalıkları ve teknoloji bağımlılık düzeyleri açısından anlamlı bir farklılık var midır?

3. Öğrenim gördükleri bölüm bağımsız değişkenine göre, üniversite öğrencilerinin Endüstri 4.0 kavramsal farkındalıkları ve teknoloji bağımlılık düzeyleri açısından anlamlı bir farklılık var midır?

4. Okudukları sınıf bağımsız değişkenine göre, üniversite öğrencilerinin Endüstri 4.0 kavramsal farkındalıkları ve teknoloji bağımlılık düzeyleri açısından anlamlı bir farklılık var mıdır?

5. Akademik not ortalamaları bağımsız değişkenine göre, üniversite öğrencilerinin Endüstri 4.0 kavramsal farkındalıkları ve teknoloji bağımlılık düzeyleri açısından anlamlı bir farklılık var midir?

6. Araştırmaya katılan öğrencilerin Endüstri 4.0 kavramsal farkındalık düzeyleri ile teknoloji bağımlılıkları arasında anlamlı bir ilişki var mıdır?

6.1. Araştırmaya katılan öğrencilerin Endüstri 4.0 kavramsal farkındalık düzeyleri ile teknolojiyi kullanma ve teknolojiyle zaman geçirme arasında anlamlı bir ilişki var mıdır?

6.2. Araştırmaya katılan öğrencilerin Endüstri 4.0 kavramsal farkındalık düzeyleri ile teknolojik istila arasında anlamlı bir ilişki var mıdır?

6.3. Araştırmaya katılan öğrencilerin Endüstri 4.0 kavramsal farkındalık düzeyleri ile teknolojiyi benimseme arasında anlamlı bir ilişki var mıdır?

6.4. Araştırmaya katılan öğrencilerin Endüstri 4.0 kavramsal farkındalık düzeyleri ile teknolojik saplantı arasında anlamlı bir ilişki var mıdır?

6.5. Araştırmaya katılan öğrencilerin Endüstri 4.0 kavramsal farkındalık düzeyleri ile iletişim sarmalı arasında anlamlı bir ilişki var mıdır?

6.6. Araştırmaya katılan öğrencilerin Endüstri 4.0 kavramsal farkındalık düzeyleri ile ruhsal ve zihinsel değişimler arasında anlamlı bir ilişki var mıdır?

Araştırma soruları ile elde edilmesi planlanan sonuçlara ilişkin araştırma genel tarama modeli kapsamında ilişkisel tarama modeline dayalı kurgulanmıştır. Bu kapsamda araştırmanın evrenini Sinop Üniversitesi Turizm İşletmeciliği ve Otelcilik Yüksekokulunda eğitim gören öğrenciler oluşturmaktadır. 2019-2020 eğitim öğretim yılında beş bölümde (konaklama işletmeciliği, yiyecek ve içecek işletmeciliği, turizm rehberliği, rekreasyon yönetimi, gastronomi ve mutfak sanatları) 803 kayıtlı öğrenci bulunmaktadır (www.turizm.sinop.edu.tr). Veriler, nicel araştırmalarda kullanılan anket tekniği ile Ekim-Kasım 2019 tarihleri arasında toplanmıştır. Kolayda örnekleme metodu ile seçilmiş 408 öğrenciden 16 öğrenci anket formunu eksik ya da hatalı doldurduğundan araştırmada 392 öğrencinin verileri değerlendirmeye alınmıştır. Anket formu 3 bölümden oluşmaktadır. Birinci bölümde öğrencilere ilişkin demografik özellikler ve diğer bilgiler, ikinci bölümde Doğan (2019) tarafından oluşturulan 39 ifade ve tek alt boyutlu "Endüstri 4.0 Kavramsal Farkındalık Ölçeği" ve üçüncü bölümde ise Küçükvardar (2019) tarafından oluşturulan 32 ifade ve 6 alt faktörden oluşan "Teknoloji Kullanım Alışkanlığ ${ }_{1}$ Ölçeği" yer almaktadır. Verilerin analizinde, ikili grupların karşılaştırılmasında bağımsız gruplar için ttesti (Independent Samples t-test) ve grup sayısının ikiden fazla olduğu karşılaştırmalarda tek yönlü varyans analizi (One-WayAnova, ANOVA) testinden yararlanılmıştır. Değişkenler arasındaki ilişkinin ortaya çıarılması amacıyla ise basit korelasyon analizinden yararlanılmıştır. Çil (2002:267-268) ve Cohen (1988:79-81), korelasyon katsayısının daima -1 ve +1 arasında değer alabileceğini ve (-) veya (+) fark etmeksizin 0,000 ve 0,30 arası değerin "zayıf ilişki", 0,31 ve 0,70 
arası değerin "orta düzey ilişki", 0,71 ve 1,00 arası değerin ise "yüksek düzey ilişki" olarak yorumlanması gerektiğini ifade etmişlerdir. Buna ek olarak bu değerlerin önlerinde yer alan (-) negatif bir ilişkiyi (bir değişkenin değeri artarken diğerinin azaldığı) ifade ederken (-) yer almayan değerlerde ise pozitif bir ilişkinin (bir değişkenin değeri artarken diğerinin de arttığı) var olduğu söylenmektedir. Araştırmada, zaman kısıtlılığının yanı sıra çalışmanın tek bir kamu üniversitesinde yürütülmesi, buna bağlı olarak elde edilen sonuçların evrene genellenmesi açısından sınırlılık olarak görülmektedir.

\section{BULGULAR}

Bu araştırma kapsamında, madde-toplam puan korelasyonu ve boyutlar arası korelasyon ölçme araçlarının güvenirlik çalışmalarında kullanılan başlıca güvenlik türleri arasında yer alan Cronbach's alpha iç tutarlılık katsayısı (Büyüköztürk, 2017) hesaplanarak Endüstri 4.0 farkındalık ölçeğine ilişkin güvenirlik katsayısı 0,91 olarak bulunmuştur. Teknoloji bağımlılık düzeyine ilişkin ölçeğin Cronbach's Alpha güvenirlik katsayısı da 0,95 olarak hesaplanmıştır. Araştırma kapsamında her iki ölçeğinde Özdamar (1999)'a göre güvenirlik katsayılarına ilişkin ölçüt değerlerinde yer alan $0,81<\alpha<1,00$ yüksek güvenilir değeri arasında yer alması ölçeğin yüksek düzeyde güvenilir olduğunu göstermektedir.

Araştırmaya katılanlara ilişkin demografik veriler Tablo 1'de verilmiştir. Bu kapsamda araştırmaya katılan öğrencilerin \%53,3'ü kadın katılımcılardan oluşurken erkek katılımcılar ise araştırma grubunun $\% 46,7^{\prime}$ sini oluşturmaktadır. Sınıf değişkeni incelendiğinde katılımcıların birinci sınıfta öğrenim görenlerin yüzdesi \%28,3'dür. İkinci sınıf katılımcı yüzdesi 12,5 iken üçüncü sınıf katılımcı yüzdesi ise 16,3'dür. Dördüncü sınıf katılımcı yüzdesi araştırma grubunun en çok katılımcı grubu olarak \%42,9'dir. Not ortalamaları değişkeninde araştırmaya katılan kişilerin büyük oranda \%65,6 ile 2.01 ile 3.00 arasında bir not ortalamaları olduğu sonucuna ulaşılmıştır. Bu grubu sırasıyla \%27,6 ile 1.01-2.00, \%4.00 ile 3.01-4.00 ve \%2,8 ile de $0.00-1.00$ arası not ortalamasına sahip öğrencilerden oluşmaktadır. Katılımcıların eğitim aldıkları bölüm değişkeni incelendiğinde turizm rehberliği öğrencilerinin \%47,7 ile en çok katılım sağlayan bölüm öğrencileri olduğu belirlenmiştir. Bu grubu \%21,9 ile yiyecek ve içecek işletmeciliği öğrencileri ile \%15,1 ile konaklama işletmeciliği öğrencileri oluşturmaktadır. Rekreasyon yönetimi ile gastronomi ve mutfak sanatları öğrencileri \%15,3 ile diğer gruplara oranla daha düşük bir katılım sağladıkları belirlenmiştir. Öğrencilerin ortaöğretim mezuniyetlerine göre dağılımları incelendiğinde katılımcıların \%62,'i Anadolu lisesi mezunu oldukları, \%28,6'sı Mesleki ve Teknik Anadolu lisesi, \%6,1 Anadolu İmam Hatip liseleri ile \%2,8 ile de Sosyal Bilimler Lisesi mezunu öğrencileridir.

Tablo 2'de öğrencilerin Endüstri 4.0 farkındalıklarına yönelik görüşleri ile cinsiyet grupları arasında farklılığın olup olmadığına ilişkin test sonuçları yer almaktadır. Tablo 2'de görüldüğü üzere öğrencilerin Endüstri 4.0 farkındalık düzeyleri ile cinsiyet değişkeni arasında anlamlı bir farklılık olduğu belirlenirken; erkek öğrencilerin Endüstri 4.0 farkındalık düzeyleri kadın öğrencilere göre daha yüksek ortalamaya sahip oldukları tespit edilmiştir. Teknoloji bağımlılığının cinsiyete göre farklılaşmadığı sonucuna ulaşılmıştır. Erkek öğrencilerin Endüstri 4.0 kavramlarına yönelik daha ilgili oldukları söylenebilir. Doğan ve Baloğlu (2020) üniversite öğrencilerinin endüstri 4.0 kavramsal farkındalık düzeylerini belirlemek amacıyla yapmış oldukları çalışmada, iki grup arasındaki puanların ortalamasında anlamlı bir farklılık olduğu belirlenmiş olup kadın öğrencilerin endüstri 4.0 kavramsal farkındalıkları erkek öğrencilerden daha düşük olduğu belirlenmiştir. Yelkikalan, Özcan ve Temel (2019) üniversite öğrencilerinin Endüstri 4.0 teknolojileri ile ilgili algıladıkları fayda, kullanım kolaylığı ve bu teknolojileri kullanıma yönelik faydalarının cinsiyet değişkenine göre farklılık gösterdiği belirlenirken kız 
öğrencilerin erkek öğrencilere göre daha düşük bir kullanım kolaylığı ve kullanıma yönelik niyet ile algı düzeyine sahip oldukları belirlenmiştir.

Tablo 1. Araştırmaya Katılanlara Yönelik Demografik Veriler

\begin{tabular}{|c|c|c|c|}
\hline \multicolumn{2}{|r|}{ Değişken } & (n) & $(\%)$ \\
\hline \multirow{2}{*}{ Cinsiyet } & Erkek & 183 & 46,7 \\
\hline & Kadın & 209 & 53,3 \\
\hline \multirow{4}{*}{ Sinıf } & 1.Sinif & 111 & 28,3 \\
\hline & 2.Sinif & 49 & 12,5 \\
\hline & 3.Sinif & 64 & 16,3 \\
\hline & 4.Sinif & 168 & 42,9 \\
\hline \multirow{4}{*}{$\begin{array}{c}\text { Not } \\
\text { ortalaması }\end{array}$} & 0-1 Aras1 & 11 & 2,8 \\
\hline & $1.01-2.00$ & 108 & 27,6 \\
\hline & $2.01-3.00$ & 257 & 65,6 \\
\hline & $3.01-4.00$ & 16 & 4,0 \\
\hline \multirow{5}{*}{ Bölüm } & Konaklama İşletmeciliği & 59 & 15,1 \\
\hline & Turizm Rehberliği & 187 & 47,7 \\
\hline & Rekreasyon Yönetimi & 344 & 8,7 \\
\hline & Gastronomi ve Mutfak Sanatları & 26 & 6,6 \\
\hline & Yiyecek ve İçecek İşletmeciliği & 86 & 21,9 \\
\hline \multirow{4}{*}{$\begin{array}{l}\text { Ortaöğretim } \\
\text { mezuniyeti }\end{array}$} & Mesleki ve Teknik Anadolu Lisesi & 112 & 28,6 \\
\hline & Sosyal Bilimler Lisesi & 11 & 2,8 \\
\hline & Anadolu Liseleri & 245 & 62,5 \\
\hline & Anadolu İmam Hatip Liseleri & 24 & 6,1 \\
\hline
\end{tabular}

Tablo 2. Üniversite Öğrencilerinin Cinsiyet Değişkenine Göre Endüstri 4.0 Kavramsal Farkındalık ve Teknoloji Bağımlılığı Düzeylerine Ait İlişkisiz Bağımsız Örneklemler T-Testi Bulguları

\begin{tabular}{|l|c|c|c|c|}
\hline \multicolumn{1}{|c|}{ Faktörler } & \multicolumn{2}{c|}{ Ortalama } & t & p \\
\hline & Kadın & Erkek & & \\
\hline Endüstri 4.0 Farkındalık & 2,62 & 2,82 & 2,31 &, 021 \\
\hline Teknoloji Bağımlılığ1 & 3,23 & 3,35 & 1,54 &, 122 \\
\hline
\end{tabular}

Tablo 3' de öğrencilerin eğitim aldıkları sınıflar ile Endüstri 4.0 farkındalık düzeyleri ve teknoloji bağımlılık düzeylerine ilişkin farklılıklarının belirlenmesine yönelik yapılan Anova (Tek yönlü varyans analzi) analizine göre değişkenler arasında anlamlı bir farklılık olduğu sonucuna ulaşılmıştır. Sınıflara göre farklılıklar incelendiğinde 4.sınıf öğrencilerinin diğer sınıflara göre daha yüksek düzeyde Endüstri 4.0 ile ilgili kavramlara farkında oldukları belirlenmiştir. Gruplar içerisinde 1.sınıf öğrencileri diğer gruplara göre en düşük düzeyde farkındalığa sahiptir. Teknoloji bağımlılığı algısında 3. sınıf öğrencilerinin diğer sınıflarda öğrenim gören öğrencilere kıyasla daha yüksek olduğu belirlenmiştir. Bu grubu sırasıyla 4. sınıf, 2. sınıf ve 1. sınıf izlemektedir. Teknoloji bağımlılığında üst sınıfların yeni üniversiteye başlayan sınıflarda öğrenim gören öğrencilere göre daha yüksek olduğu söylenebilir. Benzer bir biçimde Endüstri 4.0 farkındalığı da üst sınıflarda öğrenim gören öğrencilerin üniversiteye yeni başlayan öğrencilere göre daha yüksek olması üniversite eğitiminde ve sosyal çevrede ilgi ve farkındalık 
ile açılanabilir. Doğan ve Baloğlu (2020) üniversite öğrencilerinin endüstri 4.0 kavramlarına yönelik farkındalık düzeylerinde öğrenim gördükleri sınıflara ilişkin ortalamalarda 3.sınıf öğrencilerinin ortalamalarının diğer sınıflarda öğrenim gören öğrencilere göre daha yüksek olduğu tespit edilmiştir. Yelkikalan, Özcan ve Temel (2019) öğrenim görülen sınıf değişkenine göre Endüstri 4.0 teknolojileri ile ilgili algılanan fayda, kullanım davranışlarına ilişkin farklılığa yönelik yapılan analizlerde 1. Sınıf öğrencilerinin algıladıkları fayda düzeyi en yüksek olan grup olarak belirlenirken 4 . Sınıf öğrencileri en düşük grup ortalamasına sahip oldukları sonucuna ulaşılmıştır.

Tablo 3. Üniversite Öğrencilerinin Endüstri 4.0 Kavramsal Farkındalık Düzeylerinin ve Teknoloji Bağımlılık Düzeylerinin Öğrenim Görmekte Oldukları Sınıf Değişkenine Göre ANOVA Testi Bulguları

\begin{tabular}{|c|c|c|c|c|c|c|}
\hline \multirow[t]{2}{*}{ Faktörler } & \multicolumn{4}{|c|}{ Ortalama } & $\mathbf{F}$ & $p$ \\
\hline & 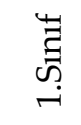 & 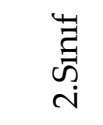 & $\begin{array}{l}\vec{\Xi} \\
\text { ज़ } \\
\text { ले }\end{array}$ & 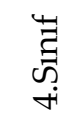 & & \\
\hline Endüstri 4.0 Farkındalık & 2,39 & 2,72 & 2,71 & 2,92 & 9,076 & 000, \\
\hline Teknoloji Bağımlılığı & 3,12 & 3,26 & 3,39 & 3,37 & 2,740 & 043, \\
\hline
\end{tabular}

Tablo 4'de araştırmaya katılan öğrencilerin eğitim-öğretim dönemlerinde elde ettikleri ortalamaları ve teknoloji bağımlılık düzeyleri ile Endüstri 4.0 farkındalıkları arasında anlamlı bir ilişki olup olmadığına yönelik yapılan analiz sonuçları verilmiştir. Yapılan analizler neticesinde değişkenler arasında anlamlı bir farklılık olmadığı sonucuna ulaşılmıştır. Doğan ve Baloğlu (2020) üniversite öğrencilerinin endüstri 4.0 kavramsal farkındalık düzeylerinin genel not ortalamalarına göre farklılaşma sonuçlarında genel not ortalaması 3-4 arasında olan öğrencilerin farkındalık düzeyleri diğer aralıklara sahip not ortalamasına öğrencilere göre daha yüksek olduğu belirlenmiştir.

Tablo 4. Üniversite Öğrencilerinin Endüstri 4.0 Kavramsal Farkındalık Düzeylerinin ve Teknoloji Bağımlılık Düzeylerinin Akademik Not Ortalamaları Değişkenine Göre ANOVA Testi Bulguları

\begin{tabular}{|c|c|c|c|c|c|c|}
\hline \multirow[t]{2}{*}{ Faktörler } & \multicolumn{4}{|c|}{ Ortalama } & $\mathbf{F}$ & $\mathrm{p}$ \\
\hline & 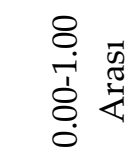 & 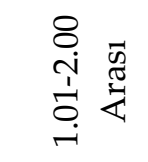 & 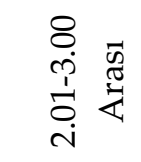 & 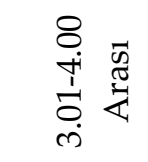 & & \\
\hline $\begin{array}{l}\text { Endüstri } 4.0 \\
\text { Farkındalık }\end{array}$ & 2,46 & 2,67 & 2,73 & 2,87 & 643 & ,588 \\
\hline Teknoloji Bağımlılığ & 3,23 & 3,43 & 3,25 & 2,96 & 2,517 & ,058 \\
\hline
\end{tabular}

Katılımcıların Endüstri 4.0 farkındalıkları ile eğitim aldıkları bölümler arasındaki farklılıklara ilişkin analiz sonuçları Tablo-5' de verilmiştir. Tablo-5'e göre Endüstri 4.0 farkındalık düzeyleri ile katılımcıların eğitim aldıkları bölümler arasında anlamlı bir farklılık olduğu sonucuna ulaşılmıştır. Konaklama işletmeciliği bölümü öğrencilerinin Endüstri 4.0 farkındalık düzeyleri 
diğer gruplara göre daha yüksek düzeydedir. Gastronomi ve mutfak sanatları öğrencilerinin Endüstri 4.0 farkındalık düzeyleri diğer gruplara oranla daha düşük ortalamaya sahip olduğu belirlenmiştir. Bu durum konaklama işletmeciliği bölümünde Endüstri 4.0 ile temel alt yapıyı oluşturmaya yönelik otomasyon programlarına sıklıkla yer verilmesi ile açılanabilir. Teknoloji bağımlılık düzeyleri ile eğitim alınan bölüm arasında ise anlamlı bir farklılık olmadığı sonucuna ulaşılmıştır. Yelkikalan, Özcan ve Temel (2019) Bölümlere göre değerlendirildiğinde işletme bölümü öğrencilerinin Endüstri 4.0 teknolojileri ile ilgili algılanan fayda düzeyinin en yüksek olduğu çocuk gelişimi bölümü en düşük olduğu bölüm olarak belirlenmiştir.

Tablo 5. Üniversite Öğrencilerinin Endüstri 4.0 Kavramsal Farkındalık ve Teknoloji Bağımlılık Düzeylerinin Öğrenim Görmekte Oldukları Bölüm Değişkenine Göre Farkındalık Düzeyleri ve ANOVA Testi Bulguları

\begin{tabular}{|c|c|c|c|c|c|c|c|}
\hline \multirow[t]{2}{*}{ Faktörler } & \multicolumn{5}{|c|}{ Ortalama } & $\mathbf{F}$ & $\mathrm{p}$ \\
\hline & 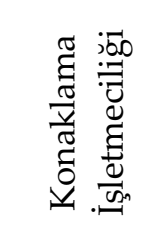 & 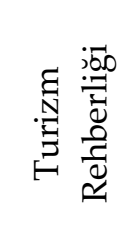 & 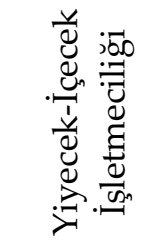 & 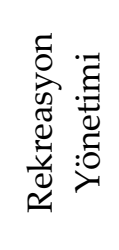 & 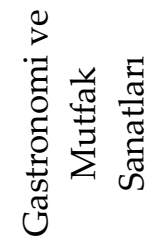 & & \\
\hline $\begin{array}{l}\text { Endüstri } 4.0 \\
\text { Farkındalık }\end{array}$ & 2,84 & 2,81 & 2,70 & 2,38 & 2,17 & 4,96 & ,001 \\
\hline $\begin{array}{l}\text { Teknoloji } \\
\text { Bağımlılı̆̆1 }\end{array}$ & 3,14 & 3,34 & 3,36 & 3,26 & 3,08 & 1,41 & ,229 \\
\hline
\end{tabular}

Tablo 6'da öğrencilerin Endüstri 4.0 farkındalık düzeyleri ve teknoloji bağımlılık düzeyleri ile ortaöğretim mezuniyet türleri arasında farklılık olup olmadığına yönelik yapılan analizler sonucunda anlamlı bir farklılık olmadığı sonucuna ulaşılmıştır. Doğan ve Baloğlu (2020) üniversite öğrencilerinin Endüstri 4.0 kavramsal farkındalık düzeylerinin ortaöğretim mezuniyet alanlarına ilişkin ortalamalarda MTAL mezunu öğrencilerin farkındalık düzeylerine ilişkin ortalamalarının diğer mezun olunan ortaöğretim gruplarına göre daha yüksek olduğu belirlenmiştir.

Tablo 6. Üniversite Öğrencilerinin Endüstri 4.0 Kavramsal Farkındalık Düzeylerinin ve Teknoloji Bağımlılık Düzeyleri ile Mezun oldukları Ortaöğretim Okulu Değişkenine Göre ANOVA Testi Bulguları

\begin{tabular}{|c|c|c|c|c|c|c|}
\hline \multirow[t]{2}{*}{ Faktörler } & \multicolumn{4}{|c|}{ Ortalama } & $\mathbf{F}$ & $\mathrm{p}$ \\
\hline & 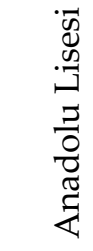 & 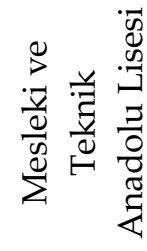 & 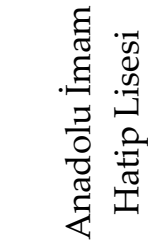 & 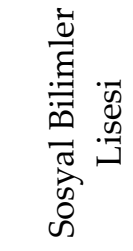 & & \\
\hline Endüstri 4.00 Farkındalık & 2,71 & 2,76 & 2,54 & 2,58 & 531 & 661 \\
\hline Teknoloji Bağımlılığı & 3,26 & 3,32 & 3,39 & 3,64 & 482 & 695 \\
\hline
\end{tabular}


Tablo 7 verildiği üzere araştırmaya katılan öğrencilerin Endüstri 4.0 kavramsal farkındalık düzeyleri ile teknoloji kullanım alışkanlıkları arasında pozitif yönlü zayıf bir korelasyon tespit edilmiştir.

Tablo 7. Üniversite Öğrencilerinin Endüstri 4.0 Kavramsal Farkındalık Düzeyleri ile Teknoloji Bağımlılık Düzeyleri Arasındaki İlişkiye Yönelik Korelasyon Analizi Bulguları

\begin{tabular}{|c|c|c|c|}
\hline Değişkenler & $\mathbf{r}$ & $\mathbf{p}$ & Yorum \\
\hline $\begin{array}{llll}\text { Endüstri } & 4.0 & \text { Kavramsal } & \text { Farkındalık } \\
\text { Düzeyleri } & & & \end{array}$ & \multirow[t]{2}{*}{ 208 } & \multirow[t]{2}{*}{, 000 } & \multirow{2}{*}{$\begin{array}{l}\text { Pozitif yönlü zayıf bir ilişki } \\
\text { vardır. }\end{array}$} \\
\hline Teknoloji Kullanım Alışkanlığı & & & \\
\hline
\end{tabular}

Yapılan korelasyon analizi neticesinde araştırmaya katılan öğrencilerin Endüstri 4.0 kavramsal farkındalık düzeyleri ile teknoloji kullanım alışkanlığının tüm alt faktörleri (teknolojiyi kullanma ve teknolojiyle zaman geçirme, teknolojik istila, teknolojik benimseme, teknolojik saplantı, iletişim sarmalı, ruhsal ve zihinsel değişimler) arasında pozitif yönlü zayıf bir ilişki saptanmıştır. Bu bulgular tablo 8 'de verilmektedir.

Tablo 8. Değişkenlere Yönelik Korelasyon Analizi Sonuçları

\begin{tabular}{|c|c|c|c|c|}
\hline \multicolumn{2}{|r|}{ Değişkenler } & $\mathbf{r}$ & $\mathbf{p}$ & Yorum \\
\hline \multirow{6}{*}{ 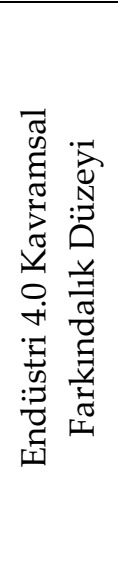 } & $\begin{array}{l}\text { Teknolojiyi kullanma ve } \\
\text { teknolojiyle zaman geçirme }\end{array}$ & 187 & , 000 & $\begin{array}{l}\text { Pozitif yönlü zayıf bir ilişki } \\
\text { vardır. }\end{array}$ \\
\hline & Teknolojik istila & 172 & ,001 & $\begin{array}{l}\text { Pozitif yönlü zayıf bir ilişki } \\
\text { vardır. }\end{array}$ \\
\hline & Teknolojik benimseme & 211 & , 000 & $\begin{array}{l}\text { Pozitif yönlü zayıf bir ilişki } \\
\text { vardır. }\end{array}$ \\
\hline & Teknolojik saplantı & ,129 & 011 & $\begin{array}{l}\text { Pozitif yönlü zayıf bir ilişki } \\
\text { vardır. }\end{array}$ \\
\hline & İletişim sarmalı & 103 & 042 & $\begin{array}{l}\text { Pozitif yönlü zayıf bir ilişki } \\
\text { vardır. }\end{array}$ \\
\hline & Ruhsal ve zihinsel değişimler & ,235 & , 000 & $\begin{array}{l}\text { Pozitif yönlü zayıf bir ilişki } \\
\text { vardır. }\end{array}$ \\
\hline
\end{tabular}

Endüstri 4.0 kavramsal farkındalık düzeylerinin alt boyutlarıyla yapılan korelasyon analizi sonuçlarına göre tüm alt boyutlarla Endüstri 4.0 kavramsal farkındalık düzeyleri arasında pozitif yönlü zayıf bir ilişki olduğu sonucuna ulaşılmıştır. Teknolojiyi kullanma ve teknoloji ile zaman geçirme, teknolojik istila, teknolojik benimseme, teknolojik saplantı, iletişim sarmalı ve ruhsal zihinsel değişimler ile Endüstri 4.0 kavramsal farkındalık düzeyleri arasında zayıf bir ilişki olduğu belirlenmiştir.

\section{TARTIŞMA, SONUÇ ve ÖNERILER}

Araştırma kapsamında beş bölümde eğitim gören (konaklama işletmeciliği, turizm rehberliği, yiyecek ve içecek işletmeciliği, rekreasyon yönetimi, gastronomi ve mutfak sanatları) öğrencilerin görüşleri kapsamında Endüstri 4.0 kavramsal farkındalıkları ile teknoloji kullanım alışkanlıkları 
arasındaki ilişkiyi ortaya koymak ve bu değişkenlerin demografik özelliklere göre farklılaşıp farklılaşmadığını belirlemek amaçlanmıştır. Bu amaç doğrultusunda araştırmaya katılan öğrenci gruplarının mezun oldukları ortaöğretim okul türleri Anadolu lisesi, Anadolu İmam Hatip lisesi, Mesleki ve teknik Anadolu lisesi, sosyal bilimler lisesinden oluşmaktadır. Bu bağlamda Endüstri 4.0 kavramına ilişkin bilgi ve farkındalıklarının belirlenen değişkenlerle farklılıklarının analizleri sonucunda Endüstri 4.0 farkındalıkları ile cinsiyet, ortalama ve mezun olunan okul türü ile anlamlı farklılık olmadığı sonucuna ulaşılmıştır. Endüstri 4.0 farkındalık düzeyinin eğitim görülen sınıf ile arasındaki farklılığın analizi ile 4.sınıf öğrencilerinin Endüstri 4.0 farkındalıklarının diğer gruplara oranla daha yüksek ortalamaya sahip oldukları bunun aksine en düşük ortalamaya sahip sınıfın ise birinci sınıf olduğu belirlenmiştir. Öğrencilerin eğitim gördükleri bölüm ile endüstri 4.0 farkındalık düzeyleri ile farklılığın belirlenmesine yönelik yapılan analizler sonucunda da konaklama işletmeciliği bölümü öğrencilerinin en yüksek düzeyde farkındalığa sahip oldukları belirlenmiştir. Bu grup içerisinde düşük düzeyde farkındalığa sahip grubun ise gastronomi ve mutfak sanatları öğrencileri olduğu ve bu grubu düşük ortalamayla rekreasyon yönetimi bölümü öğrencilerinin izlediği sonucuna ulaşılmıştır. Öğrencilerin teknoloji bağımlılık düzeyleri ile bazı demografik değişkenler (cinsiyet, mezun olunan okul, eğitim alınan bölüm, not ortalaması, eğitim alınan sınıf) arasında anlamlı farklılık olmadığı sonucuna ulaşılmıştır. Bu sonuçlarla araştırma soruları 1, 2, 3, 4, 5'e yanıt verilmiştir.

Araştırma sorusu 6'dan hareketle araştırmaya katılan öğrencilerin Endüstri 4.0 kavramsal farkındalık düzeyleri ile teknoloji kullanım alışkanlıkları arasında pozitif yönlü zayıf bir ilişkinin olduğu sonucuna ulaşılmıştır. Diğer bir ifade ile öğrencilerin Endüstri 4.0 kavramsal farkındalık düzeyleri arttıkça teknoloji kullanım alışkanlıklarının da arttığı söylenebilir. Buna ek olarak araştırma sorusu 6'nın altında yer alan alt sorulara da yanıt aramak amaciyla yapılan korelasyon analizi sonuçlarına göre öğrencilerin Endüstri 4.0 kavramsal farkındalık düzeyleri ile teknoloji kullanım alışkanlıkları altında yer alan her bir alt faktör (teknolojiyi kullanma ve teknolojiyle zaman geçirme, teknolojik istila, teknolojik benimseme, teknolojik saplantı, iletişim sarmalı, ruhsal ve zihinsel değişimler) arasında ayrı ayrı pozitif yönlü zayıf bir ilişkinin olduğu sonucuna ulaşılmıştır. Bu kapsamda da araştırma alt sorusu olan 6.1, 6.2, 6.3, 6.4, 6.5 ve 6.6'ya yanıt verilmiştir.

Yıldız ve Fırat (2020) üniversite öğrencilerinin endüstri 4.0 bilgi düzeylerini beliremeye yönelik yapmış oldukları çalışmada, öğrencilerin Endüstri 4.0 farkındalık düzeylerinin yeterli seviyede olmadığını belirlemişlerdir. Ayrıca öğrencilerin eğitim aldıkları üniversitelere göre farklılık olmadığı tespit edilmiştir. Günlük yaşama yansıyan ürünler kullanılırken altyapıyı oluşturan kavram ve teknolojilere yönelik farkındalık ve bilgi düzeylerine yönelik tutum göstermedikleri sonucuna ulaşılmıştır. Kaygisız ve Sipahi (2019) yapmış oldukları araştırmada öğrencilerin Endüstri 4.0 ile ilgili kavramlara ilişkin duyumları olduğu ve bu kavramlar içerisinde bulut bilişim, zenginleştirilmiş gerçeklik ve eklemeli üretim kavramlarına yönelik duyumlarının diğer kavramlara göre en az olduğu belirlenmiştir. Bununla birlikte kavram hakkında bilgi düzeyine sahip oldukları ancak Endüstri 4.0 ile ilgili kavramların sağlayacağı fırsatlar ve tehditler ile ilgili yeterli bilgiye sahip olmadıkları belirtilmiştir. Üniversite öğrencilerde mevcut duruma yönelik araştırmalarla farkındalık ve bilinirliğin yanı sıra sektörel araştırmalar ile Endüstri 4.0 farkındalığını belirlemeye yönelik araştırmalar her geçen gün artmaktadır. Ünlü ve Atik (2018) Türkiye'deki işletmelerin Endüstri 4.0'a geçiş ve Avrupa Birliği ile ülkeleri içerisinde durumlarına yönelik yapılan araştırmada, Endüstri 4.0 performansı en yüksek ülke Almanya olarak belirlenirken; en düşük performansa sahip ülke Letonya, Türkiye ise 29 ülke içerisinde 27. sırada olduğu tespit edilmiştir. Türkiye yapılan kümeleme analizlerinde Macaristan, Letonya ve Polonya ile aynı kümede yer aldığı belirlenmiştir. Ayrıca Türkiye'de Endüstri 4.0 kavramına ilişkin farkındalığın 2016 yılı şubat ayında gerçekleştirilen Bilim Teknoloji Yüksek Kurulu 
toplantısında alınan ciddi kararlar ile yükseldiği vurgulanmıştır. Demiral (2019) teknolojik farkındalık ve Endüstri 4.0 ile ilgili yapmış oldukları araştırmada, çalışanların nesnelerin interneti, simülasyon sistemleri, bulut bilişim, otonom robotlar, arttırılmış gerçeklik, siber güvenlik, 3D yazıcılar, sanal gerçeklik konularında teorik boyutta bilgiye sahip oldukları ancak büyük veri ve bu kavramın işletmelerde kullanımı ile ilgili yeterli bilgiye sahip olmadıkları sonucuna ulaşılmıştır. Kamber ve Bolatan (2019) Endüstri 4.0 ile üretim alanında dijitalleşme kavramına yönelik üretim endüstrisindeki firmaların bakış açılarını belirlemeye yönelik yapmış oldukları çalışmada, otomotiv ve elektronik sektörlerinde Endüstri 4.0 farkındalığının yüksek olduğu belirlenmiştir. Ayrıca araştırmada Endüstri 4.0’ a yönelik çalışmalara başlayan ve üretim sistemlerine bu teknolojik yenilikleri adapte etmeye istekli firmaların olduğu belirlenmiştir.

Değişen ve hızla gelişen teknoloji içerisinde mesleki gelişimin önemli aşamalarından birisi olan günceli ve gelişimi takip etmek bu bağlamda endüstri 4.0'e yönelik farkındalığın arttırılması önem kazanmaktadır. Özellikle mesleki gelişimin ilk ve önemli aşamalarından olan yükseköğretim kurumları eğitim ve öğretim müfredatlarında bölümlerle doğrudan ilgili, öğrencilerin mesleki gelişimlerine katkı sağlayabilecek Endüstri 4.0 kapsamında değerlendirilebilen güncel teknolojilere yer verilmesi ve bu teknolojilerin çalışma ilkelerini temel düzeyde öğretilmesi önemlidir. Özellikle turizm sektöründe sanal gerçeklik, arttırılmış gerçeklik, bulut bilişim teknolojileri, simülasyon teknolojileri, kişiye özel ürün gerçekleştirme son yıllarda üzerinde durulan ve sektörün bu gelişmeleri yakından takip ettiği söz konusudur. Bu gelişimleri yakından izleyen ve öğrencilere farkındalığın yanı sıra temel düzeyde çalışma ilkelerini öğretebilecek bir eğitim modeli üzerinde çalışılması önerilebilir. Ayrıca sektörel ihtiyaçların belirlenmesi ile sektör beklentilerine yönelik eğitim-öğretim müfredatında güncellemeler ile teknik alt yapıyı geliştirmeye yönelik çalışmalar yapılabilir. Üniversiteler bünyesinde disiplinlerarası çalışmalarla konulara ilişkin bilgi düzeyinin arttırılmasına yönelik çalışmalar yapilabilir.

\section{KAYNAKÇA}

Akben, İ. ve Avşar, İ. İ. (2018). Endüstri 4.0 ve Karanlık Üretim: Genel Bir Bakış, Türk Sosyal Bilimler Araştırmaları Dergisi, 3(1), 26-37.

Aksoy, C. (2018). Teknoloji Kullanım Ölçeğinin Geçerlilik ve Güvenilirliğinin Ölçülmesi: Üniversite Öğrencilerine Yönelik Bir Araştırma, Uluslararası Toplum Araştırmaları Dergisi, 8(15): 1111-1131.

Başar, M. (2019). Üniversite Öğrencilerinin Teknoloji Bağımlılık, Sanal Zorba ve Sanal Mağdur Olma Düzeyleri Arasındaki İlişkinin İncelenmesi, Yayımlanmamış Yüksek Lisans Tezi, Sakarya Üniversitesi, Sakarya.

Brettel, M., Friederichsen, N., Keller, M. and Rosenberg, M. (2014). How Virtualization, Decentralization and Network Building Change the Manufacturing Landscape: An Industry 4.0 Perspective, International Journal of Mechanical, Industrial Science and Engineering, 8(1):37-44.

Büyüköztürk, Ş. (2017). Sosyal Bilimler İçin Veri Analizi El Kitabı (23. Baskı). Ankara: Pegem Akademik Yayıncllı.

Cohen, J. (1988). Statistical Power Analysis for the Behavioral Sciences, (2. Edition), New York: Lawrence Erlbaum Asoiates.

Çil, B (2002). İstatistik. (3. Baskı), Ankara: Detay Yayıncılık. 
Demiral, G. (2019). Endüstri 4.0’ın İnsan Kaynaklarına Yönelik Etkileri: Teknolojik Değişim Farkındalığ Üzerine Bir Araştırma, Ekev Akademi Dergisi, 23(80), 191-208.

Doğan, O. (2019). Dijital Dönüşümün Yönetimi Sürecinde Üniversite Öğrencilerinin Endüstri 4.0 Kavramsal Farkındalık Düzeyleri, Yayımlanmamış Yüksek Lisans Tezi, Kırşehir Ahi Evran Üniversitesi, Kırşehir.

Doğan, O. ve Baloğlu, N. (2020). Üniversite Öğrencilerinin Endüstri 4.0 Kavramsal Farkındalık Düzeyleri, TÜBAV Bilim Dergisi, 13(1), 126-142.

Drath, R. and Horch, A. (2014). Industrie 4.0: Hit or Hype?, IEEE Industrial Electronics Magazine, $8(2): 56-58$.

Ertemel, A. V. ve Aydın, G. (2018). Dijital Ekonomide Teknoloji Bağımlılığı ve Çözüm Önerileri, Addicta: The Turkish Journal on Addictions 5(4): 665-690.

Ertuğrul, İ. ve Deniz, G. (2018). 4.0 Dünyası: Pazarlama 4.0 ve Endüstri 4.0, Bitlis Eren Üniversitesi Sosyal Bilimler Enstitüsü Dergisi, 7(1): 158-170.

Gürsoy, U. T., Akçay Kasapoğlu, Ö., Gürler, C. ve Bozkurt Uzan, Ş. (2019). Endüstri 4.0 Bileşenlerinin Ahp ve Dematel Yöntemleri ile İncelenmesi, International Social Sciences Studies Journal, 5(52), 7121-7132.

https://www.turizm.sinop.edu.tr/fakulte-tanitim/ [Erişim tarihi: 21.12.2019].

Hunter, F. R. (2004). Tourism and Empire: The Thomas Cook \& Son Enterprise on the Nile, Middle Eastern Studies, 40(5): 28-54.

İçli, G. (2001). Eğitim, İstihdam ve Teknoloji, Pamukkale Üniversitesi Eğitim Fakültesi Dergisi, 9(9): 65-71.

Jan Bartodziej, C. (2017). The Concept Industry 4.0: An Empirical Analysis of Technologies and Applications in Production Logistics. Wiesbaden: Springer Gabler.

Kamber, E. ve Sönmeztürk Bolatan, G. İ. (2019). Endüstri 4.0 Türkiye Farkındalığı, Mehmet Akif Ersoy Üniversitesi Sosyal Bilimler Enstitüsü Dergisi, 11(30), 836-847.

Kaygısız, E. ve Sipahi, H. (2019). Y Kuşağı Üniversite Öğrencilerinin Bireysel Yenilik ve Endüstri 4.0 Bilgi Düzeyleri Arasındaki İlişkinin İncelenmesi, Gaziantep University Journal of Social Sciences, 18(2), 922-936.

Khan, A. and Turowski, K. (2016). A Perspective on Industry 4.0: From Challenges to Opportunities in Production Systems, In Proceedings of the International Conference on Internet of Things and Big Data (IoTBD 2016), 441-448.

Küçükvardar, M. (2019). Bilişim Çağında Teknoloji Bağımlılığı ve Dijital İstila Üzerine Bir Araştırma, Yayımlanmamış Yüksek Lisans Tezi, Marmara Üniversitesi, İstanbul.

Liao, Y. (2017). Past, Present and Future of Industry 4.0 - A Systematic Literature Review and Research Agenda Proposal, International Journal of Production Research, 55(12): 3609-3629.

Nuroğlu, E. ve Nuroğlu, H. H. (2018). Türkiye ve Almanya'nın Sanayide Dijital Dönüşümü: Yol Haritaları ve Şirketlerin Karşılaştırması, Süleyman Demirel Üniversitesi İktisadi ve İdari Bilimler Fakültesi Dergisi, 23, Endüstri 4.0 ve Örgütsel Değişim Özel Sayısı, 1537-1560

Özdamar, K. (1999). Paket Programlar ile İstatistiksel Veri Analizi, Kaan Kitabevi, Eskişehir.

Özsoy, C. E. (2018). Endüstri 4.0 ve İstihdam Üzerindeki Potansiyel Etkisi, Journal of Current Researches on Business and Economics, 8(2), 249-270. 
Özsoylu, A. F. (2017). Endüstri 4.0, Çukurova Üniversitesi İ̈BF Dergisi, 21(1), 41-64.

Rojko, A. (2017). Industry 4.0 Concept: Background and Overview, International Journal of Interactive Mobile Technologies, 11(5), 77-90.

Soylu, A. (2018). Endüstri 4.0 ve Girişimcilikte Yeni Yaklaşımlar, Pamukkale Üniversitesi Sosyal Bilimler Enstitüsü Dergisi, 32, 43-57.

Toker, K. (2018). Endüstri 4.0. ve Sürdürülebilirliğe Etkileri, İstanbul Management Journal, 29(84), 51-64.

Topsakal, Y., Yüzbaşığlu, N., Çelik, P. ve Bahar, M. (2018). Turizm 4.0 - Turist 5.0: İnsan Devriminin Neden Endüstri Devrimlerinden Bir Numara Önde Olduğuna İlişkin Bakış, Journal of Tourism Intelligence and Smartness, 1 (2), 1-11.

Şimşek, T. (2019). Endüstri 4.0 ile Geleceğe Bakış ve Beklentiler. [Online]. https://www.endustri40.com/endustri-4-0-ile-gelecege-bakis-ve-beklentiler/. [Erişim tarihi: 29.01.2020].

Ünlü, F. ve Atik, H. (2018). Türkiye'deki İşletmelerin Endüstri 4.0'a Geçiş Performansı: Avrupa Birliği Ülkeleri ile Karşılaştırmalı Ampirik Analiz, Ankara Avrupa Çalışmaları Dergisi, 17(2), 431463.

W. Wahlster, W. (2012) From Industry 1.0 to Industry 4.0: Towards the 4th Industrial Revolution," In Forum Business Meets Research, 22-23 May 2012.

Widyanto, L. and Griffiths, M. (2006). 'Internet addiction': A critical review. International Journal of Mental Health and Addiction, 4(1): 31-51.

Yelkikalan, N., Özcan, S. ve Temel, K. (2019). Endüstri 4.0 Farkındalığının Belirlenmesi: Çanakkale Onsekiz Mart Üniversitesi Örneği, Girişimcilik ve Kalkınma Dergisi, 14(1), 31-44.

Yıldız, A. (2018). Endüstri 4.0 ve Akıllı Fabrikalar, Sakarya Üniversitesi Fen Bilimleri Enstitüsü Dergisi, 22 (2), 546-556.

Yıldız, S. C. ve Fırat, S. Ü. (2020). Türkiye'deki Üniversite Öğrencilerinin Endüstri 4.0 Bilgi Düzeylerinin Belirlenmesi, Endüstri Mühendisliği Dergisi, 31, 1-16.

Zhou, R. and Le Cardinal, J. (2019) Exploring the Impacts of Industry 4.0 from a Macroscopic Perspective, in Proceedings of the 22nd International Conference on Engineering Design (ICED19), Delft, The Netherlands, 5-8 August 2019. DOI:10.1017/dsi.2019.217

Zio, E. (2016). Some Challenges and Opportunities in Reliability Engineering. IEEE Transactions on Reliability, Institute of Electrical and Electronics Engineers, 65(4), 1769-1782. 